ROCZNIKI KULTUROZNAWCZE

Tom/Vol. XI, numer/number 3 - 2020

DOI: http://dx.doi.org/10.18290/rkult20113-6

JAROSŁAW MERECKI, S.D.S.

\title{
THE MYTH OF A WORLD WITHOUT DISEASE
}

\author{
Whom worse than a physician \\ Would this report become? But I consider, \\ By medicine life may be prolong'd, yet death \\ Will seize the doctor too. \\ William Shakespeare, Cymbeline $e^{1}$
}

The problem mentioned in the title of my paper makes me think of the first chapters of the Book of Genesis. The first parents, placed in the Garden of Eden, are forbidden to eat from the tree of knowledge of good and evil, but the devil tempts them with these words: If you eat from that tree, "you will not die at all" (Gen 3:4). These words remind us that the idea and the desire for life without end belongs to human history from the beginning. This vision can be justified, because it expresses man's transcendence with respect to the temporal dimension of life and urges him to seek what is beyond and what can satisfy his deepest desire of the ultimate fulfillment. According to St. Augustine a man fully satisfied with his finiteness would be a man alienated in the deepest sense of the concept of alienation, because he would be one who has detached himself from the essential dimension of his existence, that is from its transcendence with respect to the material nature. But the idea and desire of life without end can also express - as it happens in the Book of Genesis - a temptation: man can desire and try to prolong his life on earth without limits not by referring to transcendence, but limiting himself to his own resources, that is, by closing himself in the immanence of his earthly life.

Prof. Jarosław Merecki, S.D.S. - John Paul II Pontifical Theological Institute for Marriage and Family Sciences, Rome, Italy; e-mail: merecki@me.com. ORCID: https://orcid.org/0000-00018457-2935.

${ }^{1}$ William Shakespeare, "Cymbeline," in The Complete Works of William Shakespeare, ed. with a glossary by W[illiam] J[ames] Craig, MA, Trinity College, Dublin (London: Henry Pordes, 1984), 1130. 
Faced with this vision of endless earthly life we can ask two questions. One: Is it possible? And two: Would such a life be desirable? My thesis is that even if life without end in immanence were possible, it would not be desirable, because ultimately it would destroy the personal dimension of our being.

I will return to this thesis towards the end of my paper. But let us start with the question of the possibility of continuous regeneration of the organism. What until our times belonged rather to the world of imagination and science fiction (think, for example, of the visions of fantasy literature in which hibernated men survive several centuries), with the progress that science has made in our times is beginning to appear increasingly realistic. This fosters the vision (or perhaps the myth) of the world without disease, of the world in which man has the means to deal with the vulnerability of his own nature. It is perhaps no exaggeration to say that in our days medicine and especially biotecholonogies have become a sort of the tree of knowledge that promises us (almost) endless life.

In what follows I would like to briefly outline two ways of understanding the task of medicine. Inasmuch as the first is inspired precisely by the myth of the world without disease and of the victory over death, seeking to place this task as an ideal of the medical sciences, the second understands the task of medicine and science in relation to the irrepressible contingency of human nature.

\section{THE CONFRONTATION WITH THE CONTINGENCY}

Man has always had to deal with his own contingency. In our life contingency is present in different ways: as a physical contingency (our organism is vulnerable), cognitive (we commit mistakes), emotional (we are not always able to control our affections), moral (we make morally wrong choices) and ultimately existential (in the end we lose our existence). As far as possible, man has also always tried to come to terms with his contingency, while recognizing that there are limits to his actions which he must accept. The mode of contingency that touches us most deeply and that in some way summarizes all the others is the existential contingency: every expression of our contingency reminds us that we do not fully possess our life and that it ultimately escapes us. This awareness marks human life so deeply that some philosophers have defined it in relation to this experience: Martin Heidegger speaks of man as "a being-towards-death" (Sein zum Tode), whereas Søren 
Kierkeggard saw the human person as a being suffering from the "sickness unto death."

The awareness of our contingency arouses in us anxiety, even anguish. The great connoisseur of the human condition, such as Pascal, observed "that most of the occupations that fill our existence are simply a way of distracting our thoughts from reflecting on this tragic necessity that would otherwise poison all the joys of life."

The divertissement distracts us, but it's not the real way to deal with our contingency. Philosophers of the German language speak about the so-called Kontingenzbewältigung (coming to terms with the contingency) and especially Hermann Lübbe sees the main function of religion in responding to this need ${ }^{3}$. Without going into further details we can say that religion not only responds to the anguish aroused by the experience of contingency, but on the other hand it itself reinforces this awareness: in the sphere of religions that speak of creation in the strong sense, that is, as creatio ex nihilo, the idea of the contingency is further radicalized, so in a certain sense religion responds to the problem that it itself has created ${ }^{4}$.

In this perspective we can say that medicine as such exists precisely because of the constitutive contingency of man. If man were not contingent, he would not need its services. Medicine seeks to oppose contingency, that is death, and in this sense we could say that it is in search of immortality. But can we hope that this end can somehow be achieved?

Of course, religion is not the only way of the Kontingenzbewältigung. There are so many others, as Niklas Luhmann has pointed out in his systemic theory. ${ }^{5}$ One of them - and certainly one of the most powerful - is science. Modern science starts from the assumption of "subjecting nature to torture" (Francis Bacon), to force it to unravel its mysteries, to achieve the knowledge that will then be used for the good of man. In this respect the modern concept of science differs from its Aristotelian conception, in which the purpose of science was purely cognitive and contemplative, but not invasive: science did not try to change the world in which we live, but only to

\footnotetext{
${ }^{2}$ Cf. Rocco Buttiglione, L'uomo e la famiglia (Roma: Dino Editore, 1991), 145.

${ }^{3}$ Cf. Hermann LÜBBE, "Kontingenzerfahrung und Kontingenzbewältigung," in Kontingenz, ed. Edeltraut-Luise Marquard, Matthias Christen, Gerhard von Graevenitz, and Odo Marquard, "Poetik und Hermeneutik," Band 17 (München: Wilhelm Fink Verlag, 1998), 35-47.

${ }^{4}$ This is the thesis of Robert Spaemann. Cf. Robert Spaemann, Das unsterbliche Gerücht. Die Frage nach Gott und die Täuschung der Moderne (Stuttgart: Klett Cotta, 2007), 22-26.

${ }_{5}^{5}$ Cf. Sergio Belardinelli, Una sociologia senza qualità. Saggi su Luhmann (Milano: Franco Angeli Edizioni, 1993).
} 
explain it. With modern science man tries to become - as Descartes says "lord and possessor of nature" - from our point of view we can say that he wants at least to limit, if not to completely eliminate his contingency. In fact - whoever is "lord and possessor" is not subject to the forces that do not depend on him, but can himself make use of them for his own purposes.

In many ways science has in fact reduced the contingency of our lives: we are now better protected from natural disasters and we also have the means to protect ourselves much better from various diseases that not so long ago were still fatal. To be convinced of this, one only has to consider the average lifespan in the Western world.

But the new conception of science and its application, that is, the technical use of science, also has its consequences that depend on the new way of conceiving the role of reason. I would like to point out two of them: one which is on a moral level and the other which concerns the cultural and social dimension.

\section{THE NEED FOR MORALITY}

In a way we can say that Aristotelian science could be non-moral. Because the scientist did not try to intervene in the world and his action was limited to understanding it, he could argue that all his ethics were exhausted in respecting the rules of his methodology. With the arrival of modern science this is no longer the case. Since science touches the world, changes it and uses it, and thus it cannot avoid the moral question: is it legitimate what we are trying to do? For some time, the argument mentioned in this context was the argument of scientific progress. All that is needed for the progress of science would be good, that is, what increases our knowledge of the world and our possibilities to act is good. But since man himself is part of the world, it can happen that the growth of our knowledge is at the expense of the individual human being. Not everything that increases our knowledge and not everything that can serve the purposes we consider desirable is morally permissible. Stem cells research appears to be very promising because of their characteristics. However, while adult stem cells are characterized by pluripotentiality, embryonic stem cells are totipotential, i.e. from the point of view of their possible therapeutic use they can be considered superior. However, we must ask ourselves: does the fact that embryonic stem cells are superior to cells taken from adult human beings by 
itself justifies the use of human embryos for therapeutic purposes? Are we not dealing here with a clear example of the instrumental use of another human being?

I do not want to enter into the debate here on the moral status of the human embryo. What I am interested in here is to stress that in this situation a scientist cannot escape the moral question and cannot think only in terms of what is needed for science taken in the abstract or humanity understood collectively. He must seriously confront the ethical problem because if the embryo is a human being, then we are faced with the elementary requirement of justice: it is not licit to treat a human person exclusively as a means to ends that are not his own.

It seems that the part of our problem today is the typically modern conception of reason that no longer recognizes ends, but only means. It is the so-called instrumental reason that the thinkers of the Frankfurt School have already theorized and criticized. I mean: If it is argued that reason is blind to values and that these are necessarily subjective, the task of reason is limited to identifying means for ends that are given by our desires - according to David Hume's famous thesis, reason is and must be a slave of passions. Reason then becomes an instrument with which man dominates the world and transforms it according to his own desires. But a reason that knows no ends but only means will also treat the human person as a means, that is, an instrument for the realization of one's desires. In this situation the only possible form of justice is contractual justice which is the typical modern form of conceiving justice - subjects create a sphere in which they can live without being continually threatened by others. But in order to be a party to the contract, one must be able to assert one's desire for survival. If someone, like an unborn human being, is unable to do so, he or she will very easily find himself/herself outside the sphere of justice and be used as an object. It is not difficult to see that this is the fate of many human beings who have been put outside the sphere of contractual justice.

But on the other hand, instrumental reason will also have difficulties in stopping at the limits imposed by contractual justice. To give a relatively recent example: In 1998, the Ethics Committee set up by the company Geron formulated certain conditions that stem cells research had to meet. ${ }^{6}$ One of these conditions, which prohibits reproductive cloning and the creation of chimeras, seemed to be shared almost universally. A few years ago in news-

\footnotetext{
${ }^{6}$ Cf. Geron Ethics Advisory Board, "Research with Human Embryonic Stem Cells: Ethical Considerations," Hastings Center Report 29, no. 2 (March - April, 1999): 31-36.
} 
papers we could read that scientists from Newcastle University created the first hybrid cytoplasmic embryos (the news of this type had already arrived before, however, they have not been confirmed; the most famous - or infamous - case was that of the Korean Hwang who turned out to be a fraud), i.e. the human genetic material was transferred into an animal egg, with the promise of finding cures for various diseases through the production of stem cells. The embryos were killed after three days, but it is not difficult to predict that this - if this time the information is true - is only the first step. Until now, we have been talking about the therapeutic use of frozen embryos not used for in vitro fertilization. Now we are on the verge of moving on to the creation of embryos intended only for use as genetic material. Important liberal thinkers such as, for example, Jürgen Habermas warn that this step is dangerous. The hybrid word shares the etymology with the other Greek word hybris, which means unbridled human pride.

\section{THE DANGER OF HYBRIS}

The second consequence of the new way of conceiving science and reason, which we want to consider here, lies beyond the moral level on the cultural and social level. At the Molecular Biology Congress held in London in 1962, the four goals to be achieved in the near future were discussed: the world freed from infectious diseases, life without pain and without end thanks to organ transplantation and lately the improvement of man's genetic heritage. ${ }^{7}$ A year later, also in London, during a symposium dedicated to the future of mankind, a well-known English biologist Julian Huxley claimed that the time had come to change spontaneous evolution into the controlled one. Thanks to the progress of medicine many people who would have died before reaching the reproductive age, have children, but in this way they introduce genetic defects in the population. Thus, the evolution does not bring improvement, but contributes to the worsening of the human race. The time has come - says Huxley - to change this situation. Thanks to the tools of science and technology, man from the object of evolution can become its subject, not leaving evolution to the blind and irrational forces of nature, but guiding it according to his rational projects. ${ }^{8}$

\footnotetext{
${ }^{7}$ Cf. Otfried HöFfe, Moral als Preis der Moderne. Ein Versuch über Wissenschaft, Technik und Umwelt (Frankfurt a.M.: Suhrkamp Verlag, 1993), 151.

${ }^{8}$ Cf. Barbara Chyrowicz, "Antropologiczne i etyczne aspekty wykorzystania komórek macierzystych," in Komórki macierzyste - mity i rzeczywistość. Teksty wykładów wygłoszonych na sesji
} 
This vision of the task of science and medicine is not entirely new, we can find it already at the beginning of the modern age. In chapter six of Descartes' Discourse on the Method we read that medicine using scientific research "can free us from infinite diseases of both body and spirit, and perhaps even from the weakness that old age brings with it". ${ }^{9}$ As we see, the idea of "aging without becoming old" is not an invention of our time. According to Otfried Höffe, after three and a half centuries Descartes' hopes for medicine turned out to be erroneous or illusory in three respects. ${ }^{10}$ First: Progress in diagnosis is much greater than progress in therapy, so that today we know better why we die, but we die anyway. For example, some oncologists are quite pessimistic about the possibility of full victory over cancer, considering it a consequence of evolution. Secondly, the liberation from the senile weakness envisaged by Descartes has only proved possible to a certain extent. Even if we live longer today, we are not free from the diseases that an advanced age brings with itself (think for example of Alzheimer's disease) and we certainly cannot prevent the general weakening of the organism and this situation brings with it new problems for medicine and for social life in general (especially with regard to the costs of medical care and the financing of the medical system). One wonders whether with attempts to prolong life at all costs one does not fall into the trap of the "futile medical care" of which the increasingly insistent postulate of the legalization of euthanasia seems to be an understandable consequence. Third: Descartes does not take into account that the possibilities and tools that medical science gives us are morally ambiguous. Some of them, which can serve the ends posed to medicine by Descartes, are undoubtedly immoral - the example of therapeutic cloning and the therapeutic use of embryonic stem cells is among the most striking.

With everything we have said, of course, we do not want to give a generally negative opinion about the therapies offered by modern medical research

naukowej zorganizowanej przez Oddziat Polskiej Akademii Nauk i Wydział Teologiczny UAM w Poznaniu dnia 16 maja 2007 roku, ed. Andrzej Wójtowicz (Poznań: Ośrodek Wydawnictw Naukowych, 2007), 41.

9 "Il est vrai que celle qui est maintenant en usage contient peu de choses dont l'utilité soit si remarquable: mais, sans que j'aie aucun dessein de la mépriser, je m'assure qu'il n'y a personne, même de ceux qui en font profession, qui n'avoue que tout ce qu'on y sait n'est presque rien à comparaison de ce qui reste à y savoir; et qu'on se pourroit exempter d'une infinité de maladies tant du corps que de l'esprit, et même aussi peut-être de l'affoiblissement de la vieillesse, si on avoit assez de connoissance de leurs causes et de tous les remèdes dont la nature nous a pourvus" (Descartes, Discours de la méthode, chap. 6).

${ }^{10}$ Cf. Otfried HöFFe, Medizin ohne Ethik? (Frankfurt a.M.: Suhrkamp Verlag, 2002), 131-132. 
and especially biotechnology. We want to say, however, that scientists are called upon to respect in their work at least certain limitations. One of them is the postulate of justice: we cannot reduce some human persons to the status of objects just so that we can help other persons. This is a fundamental moral requirement that must be respected without exception and cannot be suspended by any calculation of utility. When the fundamental moral requirements are at stake, utility can only be understood as distributive utility, that is, as the advantage for each individual concerned, and never as collective utility, that is, the advantage that the majority of those concerned derive from something.

Another limitation of medicine comes from the irrepressible contingency of the human being. The contingency does not depend on the more or less good functioning of the organism, but is the ineliminable coordinator of the very being of man on earth. Medicine must take it into account as well. But the contemporary world has adopted rather the "Cartesian" idea of medicine according to which the doctor is "the one who, without going into any elaboration of the deeper meaning of human life, must put the machine of the body back into working order, making it functional again." ${ }^{11}$ Within instrumental rationality, which tends to subject the world to human needs and does not try to understand the meaning of what cannot be completely controlled, suffering and death appear rather as something scandalous, because they escape human control. However, if we do not make the effort to understand suffering and death, these realities of human life will nevertheless be asserted, only we will rather try to conceal them because they undermine our vision of the world. Science cannot delude us with the myth of the world without suffering, without disease and without death. Such a myth is harmful, because it raises hopes that cannot be fulfilled and on the other hand it consumes resources that could be used in more reasonable way.

\section{THE CONFRONTATION WITH DEATH}

The profession of doctor is paradoxical in this sense, that at the end of his efforts there is always defeat. If - as Benedict XVI said- "medicine is a quest to oppose death," we must say that in the end the doctor is always on the losing side. Ancient medicine has integrated this fact into its professional ethos, defining itself not only as the art of healing people, but also as the art

\footnotetext{
${ }^{11}$ Buttiglione, L'uomo e la famiglia, 152.
} 
that accompanies them when the hope of healing no longer exists and they are confronted with death. Instead, it seems that today's medicine sometimes forgets this second part of the medical ethos, trying to keep people alive even in the artificial way, practicing what has been described as "futile therapeutic care."

In his dialogues Criton and Phaedo Plato left us a touching testimony of Socrates' attitude towards death. Socrates tries to convince his friends, who have come to facilitate his escape from prison, that what matters is not life as such, but life according to virtue and justice. Socrates can renounce his life because as a virtuous man he fully possesses it. Thus, he also becomes the paradigmatic case of man's relationship to life and death. Being a person consists in possessing one's own nature; only those who are not fully immersed and identified with one's own nature can be considered as persons. In the case of man this is equivalent to being in relation to his/her living body, which is his/her existence - according to the well-known Aristotelian adage viventi viventibus esse. Now, we truly possess only what we can also leave, what we can give. Thus, in death lived as the act of leaving or giving one's life, the strongest expression of personal being is realized.

\section{BIBLIOGRAPHY}

Belardinelli, Sergio. Una sociologia senza qualità. Saggi su Luhmann. Milano: Franco Angeli Edizioni, 1993.

Buttiglione, Rocco. L'uomo e la famiglia. Roma: Dino Editore, 1991.

Chyrowicz, Barbara. "Antropologiczne i etyczne aspekty wykorzystania komórek macierzystych.” In Komórki macierzyste - mity i rzeczywistość. Teksty wykładów wygłoszonych na sesji naukowej zorganizowanej przez Oddziat Polskiej Akademii Nauk i Wydziat Teologiczny UAM w Poznaniu dnia 16 maja 2007 roku, edited by Andrzej Wójtowicz, 35-47. Poznań: Ośrodek Wydawnictw Naukowych, 2007. https://poznan.pan.pl/wp-content/uploads/2020/ 06/komorki-macierzyste-2.pdf.

Descartes, René. Discours de la méthode. In Euvres de Descartes. Tome premier. Publiées par Victor Cousin. Paris: Levrault, 1825. Project Gutenberg. Accessed Ocober 28, 2020. http://www.gutenberg.org/files/13846/13846-h/138 46-h.htm. English translation: A Discourse on Method. Translated by John Veitch. Project Gutenberg. Accessed Ocober 28, 2020. https://www.gutenberg.org/files/59/59-h/59-h.htm. Polish translation: Rozprawa o metodzie. Translated by Wanda Wojciechowska. Warszawa: PWN, 1988.

Geron Ethics Advisory Board. "Research with Human Embryonic Stem Cells: Ethical Considerations." Hastings Center Report 29, no. 2 (March - April, 1999): 31-36.

HöFfe, Otfried. Moral als Preis der Moderne. Ein Versuch über Wissenschaft, Technik und Umwelt. Frankfurt a.M.: Suhrkamp Verlag, 1993. 
HöFFe, Otfried. Sprawiedliwość polityczna. Podstawy krytycznej filozofii prawa i państwa. Translated by Jarosław Merecki. Kraków: Znak, 1999.

HöFFE, Otfried. Medizin ohne Ethik?. Frankfurt a.M.: Suhrkamp Verlag, 2002.

LüBBE, Hermann. "Kontingezerfahrung und Kontingenzbewältigung.” In Kontingenz, edited by Edeltraut-Luise Marquard, Matthias Christen, Gerhard von Graevenitz, and Odo Marquard. "Poetik und Hermeneutik." Band 17, 35-47. München: Wilhelm Fink Verlag, 1998.

Spaemann, Robert, Das unsterbliche Gerücht. Die Frage nach Gott und die Täuschung der Moderne. Stuttgart: Klett Cotta, 2007.

\section{THE MYTH OF A WORLD WITHOUT DISEASE}

\section{S u m m a ry}

Progress in contemporary medicine seems to be unveiling amazing prospects for the future of humanity. Reasearch on human stem cells, which due to their characteristics of totipotentiality (embrionic stem cells) and pluripotentiality (adult stem cells) may raise the possibility of recreating entire humann organs, inspires a whole new vision of the world in which human organism could be recreated almost endlessly. This research, however, calls for some ethical reflection. While taking stem cells from adult human persons does not provoke moral reservations, the use of stem cells taken from embrionic human persons raises the question: can such procedures be morally justified? According to the principle of justice one may never sacrifice a single human life for the sake of an advantage for many others. On the other hand we must not forget that contingency is the immutable dimension of human life on earth.

Key words: contingency; ethics; medical science; death.

\section{MIT ŚWIATA BEZ CHORÓB}

\section{Streszczenie}

Postęp współczesnej medycyny wydaje się odsłaniać dla ludzkości niesamowite perspektywy na przyszłość. Badania nad ludzkimi komórkami macierzystymi, które ze względu na swoje cechy totipotencjalności (embrionalne komórki macierzyste) i pluripotencjalności (dorosłe komórki macierzyste) mogą przynieść możliwość odtworzenia całych ludzkich organów, inspirują do zupełnie nowej wizji świata, w którym można odtworzyć organizm ludzki prawie bez ograniczeń. Te badania wymagają jednak refleksji etycznej. O ile pobieranie komórek macierzystych od dorosłego człowieka nie budzi zastrzeżeń moralnych, o tyle wykorzystanie komórek macierzystych pobranych od osób ludzkich w stadium embrionalnym rodzi pytanie, czy takie procedury mogą być moralnie uzasadnione. Zgodnie z zasadą sprawiedliwości nigdy nie można poświęcić jednego życia ludzkiego dla korzyści nawet wielu innych. $Z$ drugiej strony nie wolno zapominać, że przygodność jest niezmiennym wymiarem ludzkiego życia na ziemi.

Słowa kluczowe: przygodność; etyka; nauki medyczne; śmierć. 